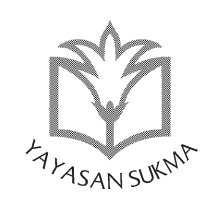

SUKMA: JURNAL PENDIDIKAN

ISSN: 2548-5105

Volume 1 Issue 1, Jan-Jun 2017, hlm. 93-129

\title{
TOWARD A HUMAN AGENCY-BASED CURRICULUM \\ A Practical Proposal at School Levels
}

\section{Khairil Azhar}

Sekolah Sukma Bangsa Lhokseumawe, Aceh, Indonesia email: besareal@gmail.com

\section{Abstrak}

Sebagai subjek belajar, siswa bisa diposisikan dalam sebuah kebijakan kurikulum sebagai agen pembelajaran atau sebaliknya cenderung menjadi subyek yang pasif. Secara teoritis, mengikuti teori yang dikembangkan oleh Alexander (2005), siswa bisa menjadi agen pembelajaran jika mereka diposisikan sebagai subyek yang memiliki atau mampu membangun agensi kemanusiaan. Agensi ini mengandaikan adanya kapasitas untuk berkehendak, mengekspresikan diri, dan evaluasi diri berdasarkan nilai-nilai kedirian yang mereka bangun. 
Berdasarkan kerangka teoritis di atas, penulis membedakan kecenderungan reseptif-reproduktif dan reflektif-transformatif dalam penyusunan kurikulum. Kecenderungan pertama memposisikan siswa sebagai subyek belajar pasif, yakni 'sekadar' menerima dan mereproduksi apa yang dipelajari atau diajarkan. Sedangkanyang kedua memberi ruang bagi sikap reflektif pada siswa sehingga menjadi alat bagi perubahan diri dan lingkungan sosialnya, yakni subyek belajar yang aktif dengan agensi kemanusiaan.

Dalam berbagai dokumen yang terkait dengan kebijakan kurikulum di Indonesia saat ini, penulis menemukan kecenderungan untuk serba mengatur cenderung dominan, yakni dengan banyaknya ragam instrumen yang terkait dengan pengaturan kurikulum. Namun demikian, terdapat peluang bagi substansiasi kurikulum dengan konsepsi agensi kemanusiaan, yakni jika konsep-konsep yang selaras atau mendukung agensi kemanusiaan dalam berbagai dokumen kebijakan dielaborasi tersebut lebih jauh, sehingga konsep-konsep yang mengkondisikan materi kurikulum reflektif-transformatif menggantikan konsep-konsep yang berkecenderungan reseptif-reproduktif.

Kata Kunci: curriculum; human agency; subjects of learning; passive recipients; agents of learning receptivereproductive; reflective-transformative

\section{Introduction}

"Yet, recent curriculum thought has tended to deny or undermine one or another aspect of the key assumption upon which a meaningful account of desirability depends - that people are the agents of their own beliefs, desires and actions."

(Alexander, 2005: 343-344) 
In the eyes of Indonesia's teachers, a curriculum is "the written, standardized subject matter guidelines provided by the national central office" instead of "the processes and products of instruction occurring in the classroom as well as outside of the classroom" (Saud and Johnston, 2006:10). It is then not far different from the official definition of curriculum in the Act on National Education System, that it is "... a set of plans and regulations about the aims, content and material of lessons and the method employed as the guidelines for the implementation of learning activities to achieve given education objectives" (UU No. 20/2003, Article 1 [19]). So, a curriculum widely understood as about a plan and administration of what to teach and learn and secondly it is about the method on how to implement the plan in learning facilitation (Permendikbud No. 67/2013; Permendikbud No. 57/2014.).

In turn, we can see in existing related government regulations that the plans, administration and methods of what and how students learn are all centralized in a whole body of an official curriculum, of which teachers are willingly or unwillingly are to follow themrespectively (such as PP No. 19/2005; PP No. $32 / 2013)$. It is then a phenomenon where the role of a teacher is more as an 'instructor', that he or she is merely accountable to implement 'formalized state-mandated curriculum' andwhile understanding a curriculum within this perspective actually positions it as more as 'an organizational framework for guiding, directing, or controlling a school's or a school system's daily classroom work' (Vasquez-Levy, 2002:117).

Analytically, related to the above phenomenon, we can assume further that one of the seemingly interminable tensions in curriculum thought is the positioning of students as the subjects of learning, whether they are the agents of their learning or conversely they are merely passive recipients of the predetermined entities of what worth knowing. More than just a romanticism such as in Rousseau's Emile (1979) or to uncritically follow the subjective tendency among existentialist curriculum thinkers (Null, 2011: 67-86), this issue is basically related to a very com- 
pelling aspect of what makes learning happens: meaningfulness and desirability (Alexander, 2005). Cognitively, for instance, such as in Bruner' emphasis ofon individuals' mastery of their learning in discovery method, meaningfulness because of both understanding of what is learned and being the agent of learning provides "a sense of excitement" (Bruner, 1999:20) that makes learning desirable.

This article mainly attempts to analyze current curriculum policy in Indonesia, in order to see the possibilities of substantiating it with human agency orientation. It also becomes the main question in the research, whether the policy provideprovides sufficient space for such substantiation or otherwise. As a theoretical framework the author uses Alexander's theorization on the conditions for human agency in a curriculum (2005). As a supporting framework, the author will use the typology of five traditions in curriculum making as differentiated by Null (2011)—comprising of systematic, pragmatic, existentialist, radical/critical, and deliberative. The typology is useful to recognize the tradition in which Indonesia's contemporary resides and to certain extent it will contribute to enrich our understanding related to the elements for the conditions of human agency both theoretically and practically.

The author found that there is a tension in the series of policy on curriculum, between strictly regulating what worth learning for students or confidently entrusting students as human beings with their learning with their own needs, interests, potentials, and identities. Yet, there is an opportunity for a human agency-based curriculum if a new policy on curriculum emphasizes a reflective-transformative predisposition at school level and gradually deemphasizes receptive-reproductive tendency in curriculum making.

\section{Theoretical Framework}

Alexander (2005) proposes three conditions of human agency in relation to a curriculum theory, namely freedom or 
self-determination, moral intelligence or self-expression, and fallibility or self-evaluation. For a practical purpose, the author prefers using self-determination, self-expression, and self-evaluation terms mainly while the other appellations will be referred when necessary, especially if the specific meanings they signify are needed. Alexander's theorization of human agency itself overlaps to greater extent with Taylor's conception of human agency (Taylor, 1985a; 1985b). He refers human beings with human agency as having "...the freedom within reasonable limits to choose their beliefs, desires and actions, the intelligence to distinguish between better and worse according to some conception of these notions, and the capacity to make mistakes in what they believe, feel and do" (Alexander, 2005:344).

Freedom, self-determination or personal autonomy is seen as a capacity that human beings should have in determining their beliefs, desires, and actions. It is the very basic condition that enables them to be the agents of their feelings, thoughts, and behaviors. If otherwise, their beings becomes meaningless, as worthwhileness and worthlessness are determined by one or more agents other than themselves. For children, it is commonly believed that their freedom or self-determination in relation to their rights as 'complete' human beings is gradually achieved as they get mature. What is critical here is that human beings cannot be positioned otherwise, that they are not free to determine what is worthwhile for themselves.

Meanwhile, moral intelligence or self-expression refers to the intelligence to distinguish between worthwhileness and worthlessness which is not only dependent on logical reasoning, but it requires corresponding horizons of significance, the values and virtues originating from human beings' socio-cultural traditions or transcendental ideals. Personal autonomy-that human beings are the agents of themselves-is only effective if there is an understanding of why something is worthwhile for them. If otherwise, the choices they make 'are not theirs or products 
of caprice'. Human moral intelligence-for which an education becomes worthwhile-functions as the instrument to make a choice among the competing conceptions of the good, to be critical, to disagree, or to be inventive.

Fallibility is the essence on which self-evaluation is possibly conducted. It is actually the capacity to engage in a particular kind of self-evaluation which is connected to the capacity to do goods or to make mistakes in what one believes, feels and do, a prerequisite to make what one does becomes meaningful. Following Frankfurt's thought, Taylor and Alexander differentiate between first order desires of human beings - such as the needs for food, procreation, and survival-and second order desires, the desire about desires-'the capacity that human beings possess to evaluate their primary preferences'. The second order can be related to a weak evaluation, such as what occurs in choosing vanilla or chocolate ice cream, which is based on 'what I feel at a particular moment'. A 'real' self-evaluation is related a strongevaluation, an assessment of the worth of a particular feeling. For instance, in a critical situation whether to save a friend or run away, one might thoroughly assess his feeling before making a decision. Here, one refers to the strong values he or she has, while he or she does not always live up to those values. A strong evaluation occurs when one is capable to go through a process of

\begin{tabular}{lll}
\hline \multicolumn{1}{c}{$\begin{array}{c}\text { Taylor's } \\
\text { Concept }\end{array}$} & $\begin{array}{c}\text { Alexander's } \\
\text { Concept }\end{array}$ & \multicolumn{1}{c}{ Explanation } \\
\hline $\begin{array}{l}\text { Self-determi- } \\
\text { nation }\end{array}$ & $\begin{array}{l}\text { Freedom/free } \\
\text { will }\end{array}$ & $\begin{array}{l}\text { Basic premise of personal autonomy based on } \\
\text { Kantian transcendental condition concept in } \\
\text { ethics }\end{array}$ \\
\hline $\begin{array}{l}\text { Self-expres- } \\
\text { sion }\end{array}$ & $\begin{array}{l}\text { Moral intelli- } \\
\text { gence }\end{array}$ & $\begin{array}{l}\text { Condition for meaningful moral choices where } \\
\text { horizons of significance (from human beings' } \\
\text { socio-cultural context) are salient based on } \\
\text { Hegelian concept on transcendental ideals }\end{array}$ \\
\hline $\begin{array}{l}\text { Self-evalua- } \\
\text { tion }\end{array}$ & Fallibility & $\begin{array}{l}\text { Condition for the meaningfulness of human } \\
\text { thinking, learning, and actions }\end{array}$ \\
\hline
\end{tabular}

Figure 1: Ethical conception of human agency (Alexander, 2005:344-346) 
self-examination of the strong values and their own desires and behaviors.

In order to make it more practical in analyzing a curriculum tradition and policy, the author differentiates between the tendency of positioning students as the agents of their learning on one end of the continuum and the tendency to position students as the passive recipients in their learning on the other end. A conception in a policy is seen as denoting agency if it advocates a reflective-transformative idea, that it contains any signification of self-determination, self-expression, or self-evaluation. Contrarily, a conception is seen as anti-agency if it merely denotes receptive-reproductive idea, that it signifies predetermination, rote reproduction of tradition, and uncritical conformism or compliance.

\section{Curriculum and its traditions}

A curriculum is actually more than just a document containing the descriptions of what and how to do in a formal course or learning. A curriculum is ideally a whole body of what, why, and how of what are worthwhile to be learned and experienced

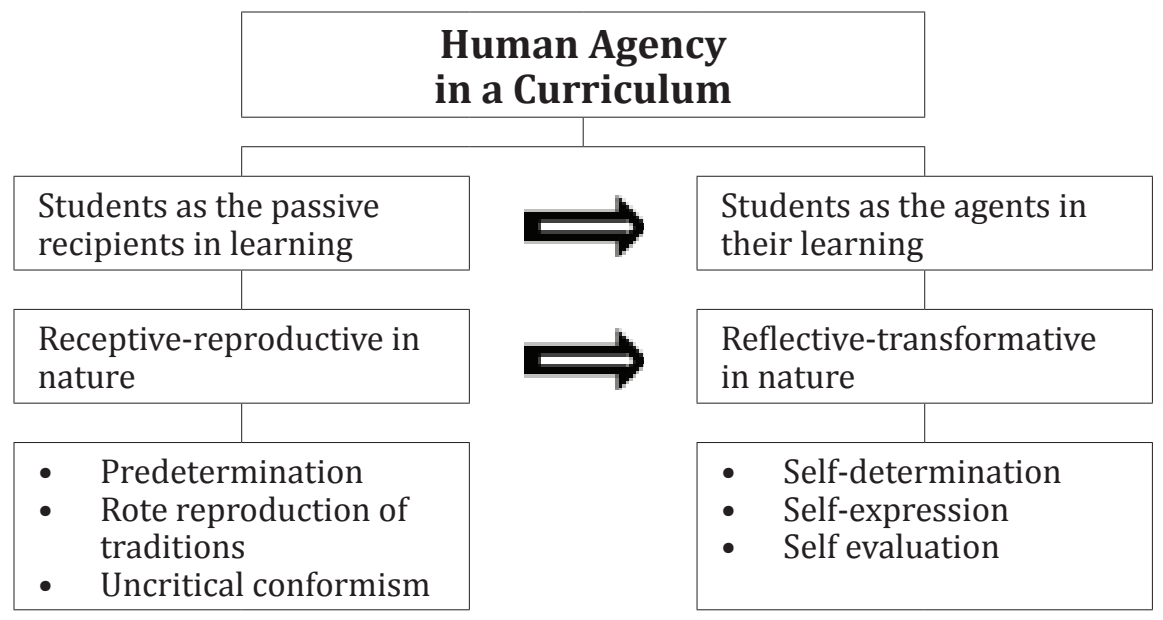

Figure 2: Human agency in a curriculum framewor (Developed from Alexander, 2005) 
by students (Schubert, 2010:36; Null, 2011:5). The question on "what" is related to what is worthwhile for students to learn, such as knowledge, skills, habits, and experiences; the question on "why" is related to the relevance or relationship of what is learned with students' beings and interests, such as their cognitive development, socio-cultural [or political] relevance, and scientific or academic importance; and the question on "how" is twofold-first, it is related to how a curriculum is planned or developed and, second, how facilitation of learning is offered, whether it is developmentally, socio-culturally, and pedagogically corresponding. And all of these should be a construction of interwoven concepts, rooted in what are there in the real world.

As a note, it is too often like an iceberg, that the tip of the curriculum making which is commonly seen. The tip itself is the tendency of the contemporary practice to lay emphasis on the how aspect (Schubert, 2010)—especially on how a curriculum should be made-while the deeper ontological (what) and axiological (why) aspects tend to be ignored. So, it seems to be forgotten that a curriculum is essentially related to the life of the students and their temporal influences in the society, and that a curriculum is a map and a compass or even a source of inspiration that enable

\begin{tabular}{|c|c|c|c|}
\hline $\begin{array}{l}\text { What worth } \\
\text { learning }\end{array}$ & $\begin{array}{l}\text { Why they are } \\
\text { worth learning }\end{array}$ & $\begin{array}{c}\text { How a curricu- } \\
\text { lum is devel- } \\
\text { oped }\end{array}$ & $\begin{array}{l}\text { How on who } \\
\text { (learners) }\end{array}$ \\
\hline $\begin{array}{l}\text { Knowledge, } \\
\text { skills, values, } \\
\text { habits, atti- } \\
\text { tudes, experi- } \\
\text { ences } \\
\text { - Human } \\
\text { agency, sub- } \\
\text { ject-matter } \\
\text { [discipline], } \\
\text { competence, } \\
\text { expertise }\end{array}$ & $\begin{array}{l}\text { Relevances: } \\
\text { - learners' needs } \\
\text { and interests } \\
\text { - Socio-cultural } \\
\text { aspects (in- } \\
\text { cluded social } \\
\text { [market] } \\
\text { demands) } \\
\text { - academic/ } \\
\text { scientific facts } \\
\text { or progress of } \\
\text { science }\end{array}$ & $\begin{array}{l}\text { Broadly, } \\
\text { dynamically, } \\
\text { rigidly, or } \\
\text { technically } \\
\text { developed } \\
\text { - Developmen- } \\
\text { tally, socio- } \\
\text { culturally, and } \\
\text { pedagogically } \\
\text { correspond- } \\
\text { ing }\end{array}$ & $\begin{array}{l}\text { - Teacher-cen- } \\
\text { tered or learn- } \\
\text { er-centered } \\
\text { in methods, } \\
\text { strategies, and } \\
\text { procedures } \\
\text { - Learners' } \\
\text { needs and } \\
\text { interests } \\
\text { are [merely] } \\
\text { consulted or } \\
\text { become the } \\
\text { starting point }\end{array}$ \\
\hline
\end{tabular}

Figure 3: Questions on curriculum 
them to have a meaningful journey along their life. The tendency of emphasizing the how takes form contemporarily in the rigid objectives and lesson plans such as the ones developed based on Tyler's Rationale model (Tyler, 1949), the Bloom taxonomical model (Bloom, 1956; Krathwohl et al, 1980) and its revised versions (Krathwohl, 2002; Marzano and Kendall, 2007).

In addition, Schwab (1971; Posner, 2004:34) based his thought on curriculum making in the question "who" in what he calls as a curriculum deliberation. Ideally, there should be representative[s] from what he called four commonplaces: the learners, the teachers, the subject matter, and the milieu. As there is a need of [scientific] coordination and process in the deliberation, a curriculum specialist must be present, so that it actually becomes five commonplaces (Null, 2011:33-36). Every commonplace has its own significant proportion in education, that there should be no subordination. In practice, however, there is no full representation of every commonplace in a curriculum team (Posner, 2004:35). Learners might be just represented by the other three, who might act as the more knowledgeable others; the teachers might be represented by 'expert' teachers with formal credentials or are likely to be appointed by the government; and the milieu is represented by the ruling government, educational boards, or some representatives of non-governmental organizations.

Among the theorizations on curriculum making, whether they are called perspectives, approaches, theories, or paradigms, the author argues that a typology constructed called 'curriculum traditions' by Null (2011) tends to be more exhaustive. Generally, Null identifies five traditions-namely systematic, pragmatic, existentialist, radical and deliberative-based on two dimensions (Null, 2011). First, a curriculum may be authored with the assumption that it should be committed to certain ideals-a priori knowledge, objective knowledge, theory, and school system. On the other end of the dimension, a curriculum might be built on the idea of rejecting any ideals and leaning on learners personal experiences, subjective knowledge, practice, application and 
individual schools. Second, a curriculum might be based on the idea of accepting the existence of social institutions where social reforms is relatively unnecessary. On the other end, a curriculum is regarded as a means with which social reforms may occur because the existing social institutions are regarded as in need of change.

In addition, Null also bases his categorization on Schwab's five commonplaces in curriculum making, namely teachers, learners, context, subject-matters and curriculum specialists. He then identifies the different emphasis of each tradition on all of these commonplaces. Yet, the author will only use the aspects that are related to seeing students as the agents of learning in a curriculum tradition and do not discuss the rest.

\section{Findings: Indonesia' Contemporary Curriculum Policy}

In terms of education, especially on curriculum and pedagogy, general educational ideals stated in Indonesia's constitution (UUD 1945) is legally operationalized in at least four stages before they materialize in school learning activities. There should be, first, a specific law or act that administers what and how Indonesia's education should be running (now it is Act No. 20/2003 [referred as UU No.20/2003]). To make it more operational, the government, second, ordains what is called as Government Regulation (the latest is No. 32/2013 on National Education System [referred as PP No. 32/2013]) which represents the ruling government's policies in education, such as how a curriculum should be. Third, the government regulation is translated into the regulation of Education and Culture Minister (the latest is No. 24/2016 [referred as Permendikbud No. 24/2016]) which contains the official frameworks or standards. Fourth, there is an implemented curriculum at schools which is called school-based curriculum and is developed by teachers. Relatedly, teachers are also required to prepare syllabi, lesson plans, and assessment mechanisms as their basis for teaching/learning processes.

Since 2003, Indonesian curriculum is competency-based 
Toward A Human Agency-Based Curriculum

\begin{tabular}{|c|c|c|c|c|}
\hline Systematic & Pragmatic & $\begin{array}{c}\text { Existential- } \\
\text { ist }\end{array}$ & Radical & $\begin{array}{l}\text { Delibera- } \\
\text { tive }\end{array}$ \\
\hline $\begin{array}{l}\text { A curricu- } \\
\text { lum is pro- } \\
\text { duced in a } \\
\text { systematic } \\
\text { mechaniza- } \\
\text { tion which } \\
\text { yields } \\
\text { objective- } \\
\text { prescriptive } \\
\text { ideals and } \\
\text { applied } \\
\text { through } \\
\text { managerial- } \\
\text { ism. }\end{array}$ & $\begin{array}{l}\text { A curricu- } \\
\text { lum is } \\
\text { adjusted } \\
\text { based on } \\
\text { the factual } \\
\text { workability } \\
\text { of ideas in a } \\
\text { given time } \\
\text { and place } \\
\text { (context)- } \\
\text { workable } \\
\text { skills, } \\
\text { subjects, } \\
\text { and experi- } \\
\text { ences. }\end{array}$ & $\begin{array}{l}\text { A curricu- } \\
\text { lum should } \\
\text { be self- } \\
\text { directed, } \\
\text { based on } \\
\text { the needs } \\
\text { and inter- } \\
\text { ests of the } \\
\text { students- } \\
\text { their per- } \\
\text { sonal desire } \\
\text { and choice. }\end{array}$ & $\begin{array}{l}\text { A curricu- } \\
\text { lum should } \\
\text { be based on } \\
\text { the need of } \\
\text { liberating } \\
\text { people from } \\
\text { false con- } \\
\text { sciousness, } \\
\text { hegemony, } \\
\text { or oppres- } \\
\text { sion. }\end{array}$ & $\begin{array}{l}\text { A curricu- } \\
\text { lum is } \\
\text { constructed } \\
\text { delibera- } \\
\text { tively in a } \\
\text { social pro- } \\
\text { cess where } \\
\text { moral, } \\
\text { practical } \\
\text { and social } \\
\text { aspects are } \\
\text { considered. }\end{array}$ \\
\hline $\begin{array}{l}\text { Students } \\
\text { tend to } \\
\text { be in the } \\
\text { position } \\
\text { of passive } \\
\text { recipients. } \\
\text { What worth } \\
\text { learning are } \\
\text { prescribed/ } \\
\text { predeter- } \\
\text { mined. }\end{array}$ & $\begin{array}{l}\text { Students' } \\
\text { experi- } \\
\text { ences are } \\
\text { important } \\
\text { as informed } \\
\text { by devel- } \\
\text { opmental } \\
\text { psychology } \\
\text { in a given } \\
\text { context. }\end{array}$ & $\begin{array}{l}\text { Students' } \\
\text { self-real- } \\
\text { ization is } \\
\text { everything. } \\
\text { There is no } \\
\text { objectiv- } \\
\text { ity as in } \\
\text { systematic } \\
\text { tradition. } \\
\text { There is } \\
\text { only subjec- } \\
\text { tivity. }\end{array}$ & $\begin{array}{l}\text { Students } \\
\text { are to be } \\
\text { liberated } \\
\text { through } \\
\text { learning } \\
\text { from unjust } \\
\text { ideology } \\
\text { and power } \\
\text { relation- } \\
\text { till they can } \\
\text { see it. }\end{array}$ & $\begin{array}{l}\text { Students } \\
\text { are both } \\
\text { personal } \\
\text { and social } \\
\text { beings. An } \\
\text { education } \\
\text { is to help } \\
\text { them to be } \\
\text { the agents } \\
\text { in both } \\
\text { lives. }\end{array}$ \\
\hline
\end{tabular}

Figure 4: Curriculum traditions and positioning of students (Developed from Null, 2011)

and legalized in the Act No.20/2003 on National education system, and materialized initially as a pilot project in form of 2004 competency-based curriculum (KBK 2004). As a manifestation of educational reform in terms of decentralization yet with the same competency-based principle, there was then a school-based curriculum (KTSP 2006). Indonesian 2013 Curriculum, which is now in use, is basically a revised model of the two previous curricula, which structurally is claimed in the framing document as applying (or endorsing) thematic-based, scientific approach, dis- 
covery, problem-based, and project-based in teaching-learning processes (Kemendikbud, 2013:63).

\section{Before a curriculum: a philosophical and policy tension in Indonesia's education}

Philosophically, Indonesia's education has been built with strong emancipatory ideation. In the Constitution, the notion of anti-colonialism, independence, sovereignty, will to freedom, and progressiveness are unambiguously expressed. The state should "enhance the intellectual capacity of the nation" or "to advance the life of the people [through education]" (UUD 1945, Preamble). The original Indonesian keyword 'mencerdaskan' which is translated here as 'to enhance' and 'to advance' also generically means 'to educate', 'to enlighten', 'to develop', 'to improve', 'to elevate', or 'to sharpen' (KBBI, 2008:279; Stevens \& Tellings, 2010:218). Furthermore, the ideation is based on monotheism, humanity, unity, democracy, and social justice.

As education is related to human development, in which human rights are prerequisite, the Constitution asserts that every individual has equal rights to,

“... get education and to benefit from science and technology, arts and culture, for the purpose of improving the quality of his/her life and for the welfare of the human race (Article 28A [1]); ... to choose one's education and the way they will be educated" (Article 28E [1]); [and very principally the rights to] ... express his/her thoughts and views" (Article 28E [2]); [and to have] freedom of thought and conscience (Article 28I [1])."

In short, the principles upon which Indonesia's education is built is in line with the rights to education as stated in the Universal Declaration of Human Rights, that everyone has the right to education and that education "... shall be directed to the full development of the human personality and to the strengthening of respect for human rights and fundamental freedoms" (UDHR, Article 26 [2]). Up to this point, therefore, the 
Constitution positions children or learners in education as the agents of their learning. They are to develop themselves through education instead of to be developed or shaped by an institution or somebody or some people to be other than themselves. The government, after all, is obligated to facilitate the advancement of civilization and welfare of human beings (Article 31 [5]).

In the act on national education system, in line with the spirit that human beings learn because it is a way to develop themselves, education is officially defined as,

“... conscious and well-planned effort in creating a learning environment and learning process so that learners will be able to develop their full potential for acquiring spiritual and religious strengths, self-control, personality, intelligence, morals and noble character, and skills - all of which one needs for him/herself, the society, the nation, and the State" (UU No. 20/2013, Article 1 [1]).

In the same tone, education is also defined as human beings' effort "... to realize their potentials through learning and/ or other education activities which are socially recognizable" (UU No. 20/2013, Supplement).

Education is also understood as"... rooted in religious values, national cultures, and responsive to the change of time" (Article 1 [2]) and it is "... to inculcate in young minds the respect for human rights, for cultural pluralism and learning to live together, promote morals and character building as well as unity in diversity (BhinnekaTunggal Eka) in the spirit of brotherhood and solidarity" (UU No. 20/2003). Accordingly, the Act on national education system noticeably expresses that,

"a national education system should ensure equal opportunity, improvement of quality and relevance and efficiency in management to meet various challenges in the wake of changes of local, national and global lives [which therefore] ... requires a well-planned, well-directed, and sustainable education reform" (Consideration B). 
The Act furthermore reiterates the significance of sociocultural contexts in education, philosophy and the temporality of education (Article 1 [2]); the localities and peculiarities of socio-cultural aspects [16]; the principles of democracy, justice, indiscrimination, human rights religiosity, cultural values, and diversities in managing education (Article 4 [1]; and the obligation of the teachers and educational staffs to "... create meaningful, joyful, creative, dynamic, and dialogic educational environment" (Article 40 [2a]).

In providing and managing an education, there are guiding principles. It should be managed democratically, equally and nondiscriminatorily, and is based on human rights, religious values, cultural values, and national pluralism (UU No. 20/2003, Article 4 [1]). In practice, it should be managed systematically within an open system - a multi entry and exit system with manageable flexibility such as in choosing a program and its accomplishment timing-and multi-meanings-a polyvalent education whereby the processes are oriented to the inculcation of cultural values, empowerment, character building and personality development, and development of various life skills (Article 4 [2]).

Accordingly, education should be understood as a life-long process, that there are different types of education of which people can choose without having to be restrained by their ages. An education itself is conducted through modeling, motivating, and developing creativity as the fundamentals in the processes of learning. In terms of contents, in the beginning, education is believed to be dependent on the acquisition of reading, writing, and arithmetic abilities. In the process of education, the involvement of wider community is seen pivotal, not only in terms of participation in monitoring sense, but also related to how education can be facilitated better in its multiple aspects.

Structurally, local community is legally endorsed to involve actively in managing education. There are board of educationdefined as "... an independent institution consisting of various components of an education community devoted to education" 
and school committee-defined as “... independent institution consisting of parents/children's guardians, school communities, and community figures devoted to education" (UU No. 20/2003, Article 1 [24-25]). 1) Community's involvement can materialize related to "... quality improvement of educational services, including planning, monitoring, and evaluation of education" (Article 56 [1]). Educational board is an independent institution that can support with advices, economic supports, and monitoring at national, provincial, and district/municipal levels. With similar functions, a school committee works at a unit of education level.

The vision of Indonesian national education is stated as "to bring into being the education system as a strong and respected social institution to empower all citizens of Indonesia to become enlightened human beings who are able to keep abreast of the challenges of the time" (UU No. 20/2003). Accordingly, there are five missions to be accomplished.

“(1) To strive for the broadening and even distribution of opportunities for quality education for all Indonesian citizens; (2) to assist and facilitate the development of their potentials, from early childhood throughout life, in order to bring into being a learning society; (3) to improve quality of educational inputs and process to optimize the formation of moral character building; (4) to enhance the professionalism and accountability of educational institutions as centers for acculturation of sciences, skills, experiences, attitudes, and values based on national and global standards; and (5) to empower community participation in the provision of education, based on the principles of autonomy in the context of the unity of the Republic of Indonesia" (UU No. 20/2003, Supplement).

Conceptually overlapping to certain extent, there are also 'purpose', 'function', and 'strategies of development' of Indonesia national education system. In the Constitution, the purpose of education is to elevate one's religiosity (faith and spirituality) and morality, upon which is believed that the quality of the life 
of the people or nation will advance (Article 31 [3] while in the Act on National Education System it is "to develop learners' potentials so that they become faithful and pious to the Almighty God, possess moral and noble individuals, be physically healthy, are knowledgeable, skillful, and independent, as well as become democratic and responsible citizens" (Article 3).

The function of education is meant as what education contributes to the nation building as a continuous process. It is then stated that education functions "to develop the capacity, character and dignified civilization of the nation in order to enhance its intelligent way of life [for an intelligent nation]" (UU No. 20/2003, Article 3). More practically, education functions as (1) a unifying instrument [of the people of the nation]; (2) an instrument to equally participate in nation building; and (3) an instrument through which all citizens can optimally develop themselves (PP No. 19/2005, Supplement).

Strategically, in order to attain the purpose and to make education function there are thirteen strategies commended in the Act on education:

“(1) implementation of religious and moral education; (2) development and implementation of competence-based curriculum; (3) educative and dialogic (deliberative) processes of learning; (4) empowering educational evaluation-accreditation-certification; (5) provision of educative learning facilities; (7) the provision of educational funding based on principles of equality and equity; (8) the provision of open education and equality in education; (9) the implementation of compulsory basic education; (10) the implementation of autonomous management of education; (11) the empowerment of community roles; (12) the center of community empowerment and development; and (13) the implementation of the monitoring activities in national education system" (UU No. 20/2003, Supplement, Part 1).

Related to the research, the first three strategies are most relevant. While the first is more as a restatement of what the 
Constitution commends, the second that a curriculum should be a competence-based is educationally problematic, since it refers specifically to a type of curriculum which might be thought as the best in a time, a place and by certain people. It is then simply reasonable to argue that there might be one or more alternatives that might have their own distinctiveness in different contexts and temporalities. Legally, actually, it contradicts the spirit of openness and eclecticism in the Constitution as in the preamble and Article 28A and 28E, while educationally, as education science is dynamic, such specification becomes an unnecessary limitation that forces the practitioners to only work within a single officially-determined curriculum.

Accordingly, a narrower translation appears in government regulation, that an action program of the government in terms of education is to "... reorganize [change] school curricula in order to produce schooling outputs that are able to meet the needs of human resources so that they contribute to the national and local [economic] growth" (PP, No. 32/2013, Supplement). What crucially can be seen here is that learners are not anymore seen as human beings with self-autonomy, yet they are positioned as the to-be-processed 'crudes' in an educational machine, with the aim that they will think and act as what the society dictates and needs according to the interpretation of the policy makers.

Furthermore, quality education is determined based on its relevance with the needs of the society and global competitiveness (PP No. 19/2005, Supplement); national education standards are adapted in accordance with the societal, local, national and global dynamic developments; and for an intelligent nation is required a national commitment on quality enhancement and nation competitiveness in education. So, these considerations then become an entrapment that the policy makers keep centralizing the education system through repeatedly rearranging the standards of minimum competences, contents, processes, assessments and evaluations, and curriculum changes (PP No. 32/2013, Considerance). 
Interestingly, these notions can be seen as contradicting what is called as educational reform in the same government regulation. There are three progressive points in it while the last point might be intended for quality control yet it is very likely to dampen the other three as it assumptively enables excessive controls through administration and managerialism. The notions in the reform comprise of positioning students the agents of learning, schooling outputs as the subjects for nation development (building), socio-culturally integrated learners, and benchmarking at school level.

To sum up, based on the above exploration, it can be said that there is a tension in both philosophical and corresponding policies enacted, which subsequently influence the policies on curriculum, or let us say it as an ambivalence if not ambiguity. On one hand, it can be seen clearly that human beings are willfully positioned as agents of their life-and therefore of their learning-in the Constitution and to different extent in the Act on national educational system and government regulations. However, on the other hand, the tendency to regulate, systematize, control, or centralize educational practices, mainly administratively, jeopardizes schools' and teachers' autonomies, which in turn endangers the intention to let the citizens wishing to educate themselves as human beings become the agents of their own learning. And unfortunately, in such tension, the zest to regulate tends to triumph, that an education becomes very procedural or administrative and the attention paid to the students as the agents of learning significantly decreases. In the following discussion on the policies on curriculum, the tendency to regulate and control education administratively can be seen through the use of a lot of terms, rhetoric, and procedures.

\section{Indonesia's contemporary official curriculum: normative premises and promises}

Understanding Indonesia's curriculum system-especially with its numerous and overlapping terms, procedures, or admin- 


\begin{tabular}{ll}
\hline \hline & $\begin{array}{l}\text { Education is managed to be a long life process of } \\
\text { enculturation and empowerment of learners, where } \\
\text { behavioral modelling, personal will, and potential as }\end{array}$ \\
$\begin{array}{l}\text { Students as the } \\
\text { agents of learn- } \\
\text { ing }\end{array}$ & $\begin{array}{l}\text { [should] be a shift of paradigm from teaching orienta- } \\
\text { tion to learning orientation, where students' role in } \\
\text { constructing their knowledge and skills are empha- } \\
\text { sized. }\end{array}$ \\
\hline $\begin{array}{l}\text { Schooling } \\
\text { outputs as the } \\
\text { subjects [agents] } \\
\text { for [nation] } \\
\text { development }\end{array}$ & $\begin{array}{l}\text { Related to socio-cultural [or nation] development } \\
\text { there [should] be a shift from human beings as the } \\
\text { agents] of development. As the subjects of develop- } \\
\text { ment, there are physical, psychological, and academic } \\
\text { and other prerequisites which are acquired through } \\
\text { education. }\end{array}$ \\
\hline $\begin{array}{l}\text { Socio-culturally } \\
\text { integrated learn- } \\
\text { ers }\end{array}$ & $\begin{array}{l}\text { Socio-cultural attachment is emphasized, where the } \\
\text { individual and the social of human beings should be } \\
\text { harmonized. Included here is the importance of indi- } \\
\text { vidual and social identity development. }\end{array}$ \\
\hline & $\begin{array}{l}\text { Benchmarking at school level in terms of (1) learn- } \\
\text { ing contents, (2) democratic, educative, motivat- } \\
\text { ing, and dialogic processes dialogic; (3) quality and } \\
\text { measurable outputs, (4) teacher professionalism, (5) } \\
\text { supportive-learning facilities, (6) school-empowering } \\
\text { management, and (7) evaluation, accreditation, and } \\
\text { certification for continuous quality development. }\end{array}$ \\
\hline Benchmarking school level &
\end{tabular}

Figure 5: Educational reform (simplified from PP No. 19/2005, Supplement [I])

istrative affairs-is never an easy task, even if one has already been a teacher for years. Speaking in terms of the usefulness of those terms and procedures in relation to everyday teaching-learning activities, many (if not most) of them might only preparebe prepared and useused once in a five-year term, especially when the time for school accreditation comes. So, many of us, teachers, talk about them as 'necessary wastefulness' as grade A, B, or C is important related to a school's reputation, not only in the eyes of the state educational officials but also among the members of the society with competitive mindsets. Regarding terminology, in which a term represents one or more procedures 
or administrative affairs, the following table might tell us a little about the complicatedness as an introductory map. There are three dominant words are used in the policy documents, namely 'curriculum', 'competence' and 'standard'.

To get rid of the complicatedness, in this part of the article, the author will focus on the parts of the curriculum policy that directly relate to how students as the subjects of learning are positioned. The author, therefore, will limit the discussion on (1) foundations, rational, and characteristics of the 2013 curriculum and (2) how an official curriculum is regulated. One interesting finding here is the tension between the normative premises and promises of Indonesian 2013 curriculum and how it is regulated, where centralization, systematization, or managerialism contradict the philosophical, sociological, psycho-pedagogical, and theoretical foundations as well as the rational and characteristics of the curriculum. On one side, the curriculum tends to be authored as a reflective-transformative one, while so far,

\begin{tabular}{|c|c|c|}
\hline $\begin{array}{l}\text { Terms with the word } \\
\text { 'standard' }\end{array}$ & $\begin{array}{l}\text { Terms with the word } \\
\text { 'curriculum' }\end{array}$ & $\begin{array}{l}\text { Terms with the word } \\
\text { 'competence' }\end{array}$ \\
\hline $\begin{array}{l}\text { national education } \\
\text { standard } \\
\text { standard of contents } \\
\text { standard of processes } \\
\text { standard of output } \\
\text { competences } \\
\text { standard of educa- } \\
\text { tional personnel } \\
\text { standard of facilities } \\
\text { and equipment } \\
\text { standard of manage- } \\
\text { ment } \\
\text { standard of budgeting } \\
\text { standard of educa- } \\
\text { tional evaluation } \\
\text {.... }\end{array}$ & $\begin{array}{l}\text { dimensions of cur- } \\
\text { riculum } \\
\text { structure of curricu- } \\
\text { lum } \\
\text { basic framework of } \\
\text { curriculum } \\
\text { school-based curricu- } \\
\text { lum } \\
\text { curriculum develop- } \\
\text { ment } \\
\text { characteristics of cur- } \\
\text { riculum } \\
\text { curriculum document } \\
\text { curriculum evaluation } \\
\text { foundations of cur- } \\
\text { riculum } \\
\text {.... }\end{array}$ & $\begin{array}{l}\text { competence-based } \\
\text { curriculum } \\
\text { core competence } \\
\text { basic competence } \\
\text { output competence } \\
\text { standards } \\
\text { levels of competence } \\
\text { Indonesia's compe- } \\
\text { tence qualification } \\
\text { competence complex- } \\
\text { ity } \\
\text { competence certifi- } \\
\text { cate } \\
\text { subject-matter com- } \\
\text { petence } \\
\text {.... }\end{array}$ \\
\hline
\end{tabular}

Figure 6: Three dominant terms in use in Indonesia's curriculum 
the related regulations and arrangements endorses receptivereproductive tendency. Consequently, there are only vague if not normative expressions in the policies researched about the real positioning of the students as the subjects of learning, whether they are the agents of learning with the conditions of self-determination, self-expression, and self-evaluation.

\section{Foundations, rational, and the characteristics of the curriculum}

The contemporary curriculum used in Indonesia, 2013 Curriculum, is claimed to have been built on four foundations, namely philosophical, sociological, psycho-pedagogical, and theoretical (Permendikbud, No. 67/2013, Appendix). First, philosophical foundation is related to how a curriculum can develop individual and social life of the learners, where there are interrelated notions of religion, arts, creativity, communication, values, multiple intelligences, individual potentials, society, nation, and humanity. And the list can be much longer as there is a statement in the regulation about eclecticism and open principle in curriculum making.

However, using Null's typology, what can be seen then is the tendency toward systematic tradition with dense traditionalism, with the indication of emphasizing 'what works in the adult world' as what worth learning. While ideals become important, preserving existing institutions and constructing the new ones becomes inevitable. While there is no more theoretical explication, such as in a more comprehensive curriculum deliberation, the inclusion of a list of big ideas becomes meaningless. For instance, the curriculum policy documents keep listing 'big words' or 'ideal world' and just include the connections with the problems in the real world as far as in the expressions 'challenges' and 'problem solving'. So, when world is just represented by good things, how the students will be able to deal with the tension between the reception of traditions and the building of reflective capacity, as being critical is 'subversive' in an idealized world? 


\begin{tabular}{|c|c|}
\hline $\begin{array}{l}\text { Philosophical } \\
\text { Foundations }\end{array}$ & $\begin{array}{l}\text { - Education is rooted in socio-cultural context, with an } \\
\text { emphasis on the nation's past, present and future } \\
\text { - Learners as the creative heirs of their society's tradi- } \\
\text { tions, socio-cultural context as a determinant factor } \\
\text { in building reasoning capacity, and socio-cultural } \\
\text { heritages as the source of identities, personal prefer- } \\
\text { ences, interactions } \\
\text { - Education as a means to develop intellectual and aca- } \\
\text { demic capacities (essentialism) in specified subjects } \\
\text { - Experimentalism (or experientialism?) and social- } \\
\text { reconstructivism for the development of intellectual, } \\
\text { social, emphatic, and participatory capacities of learn- } \\
\text { ers, so that they are able to solve individual and social } \\
\text { problems reflectively }\end{array}$ \\
\hline $\begin{array}{l}\text { Sociological } \\
\text { foundations }\end{array}$ & $\begin{array}{l}\text { - The inevitability of the needs to adapt in the dynamic } \\
\text { changes as the consequence of the development of } \\
\text { sciences, technology, and arts and the emergence of } \\
\text { new professions } \\
\text { - The need for knowledge-based society as the answer } \\
\text { for the continuous changes, where the changes of cur- } \\
\text { riculum is also inevitable }\end{array}$ \\
\hline $\begin{array}{l}\text { Psycho-peda- } \\
\text { gogical founda- } \\
\text { tions }\end{array}$ & $\begin{array}{l}\text { Education is based on the development of the learn- } \\
\text { ers within their living and temporal contexts as } \\
\text { understood in transformative pedagogy. Education } \\
\text { is the means through which students are positioned } \\
\text { as gradually and psychologically maturing human } \\
\text { beings. }\end{array}$ \\
\hline $\begin{array}{l}\text { Theoretical } \\
\text { Foundations }\end{array}$ & $\begin{array}{l}\text { - Standard-based education } \\
\text { - Competency-based curriculum with national stan- } \\
\text { dards } \\
\text { - Taught curriculum and learned-curriculum }\end{array}$ \\
\hline
\end{tabular}

Figure 7: Philosophical Foundations (abridged from the Appendix of Permendikbud No.67/2013)

Another clear example of problem that is unsolved here is how existentialism in curriculum making with its subjective tendency and essentialism with its objective inclination are 'negotiated'? In the real world of education, the tendency to emphasize subject-matters, in the name of intellectuality and academic orientation, deemphasizes the importance of subjectivity. Meanwhile, human beings are not to be programmed machines as in extreme behaviorism or organisms living with absolute relativ- 
ism as in extreme academic structuralism.

The philosophical foundations stated here, therefore, unclearly defines the underpinnings on which the curriculum is built upon. The logical consequence then is that the philosophical foundations of the curriculum is not likely to be parallel with the competence standards or other related materials in the curriculum.

Second, sociological foundations of the curriculum, parallel with the orientation in systematic tradition in the philosophical foundations, emphasizes the inevitability of societal changes as the consequence of the development of sciences, technology, and arts and the emergence of new professions and the inevitable need for knowledge-based society. Similar idea is also reiterated in the rational of the curriculum and in higher regulations. Even there is an emphasis in the rational on the importance of considering Indonesia's poor achievement in international academic competitions.

The important notions to notice in this foundation then is the significance of building economic-related capacities, competitiveness, and knowledge-based society. It is as these ideas represent untamed forces to systematize, regulate and control curriculum making and its administration at school levels. Using Null's curriculum tradition dimensions, it is very predictable that there will ideals imposed and preservation of existing institutions for a manageable status quo, which representing the interests of the society. The standards in a curriculum, for instance, will be designed to serve such needs and the students are to be passive recipients instead of active agents withas the opportunities to choose and decide or at least to negotiate are reduced if not negated. In this situation, the individual aspects of human beings are tamed and structured into the social, asaccording to what are thought best by policy makers and curriculum authors.

What takes place, in another word, the chance for human agency in learning, that students are the real agents in their learning, becomes diminished into what Alexander signifies 
as merely "for the purpose of packaging predetermined social objectives to make them appealing to students, rather than to actively engage their genuine aspirations and concerns" (Alexander, 2005:348).

Third, psycho-pedagogical foundation of the curriculum emphasizes the importance of an education that is based on the psychological development of the learners within their living and temporal contexts as in transformative pedagogy, and that students are positioned as gradually maturing human beings. However, while there is no reference and more detailed explanation on what is meant with this foundation in any of related official documents, it actually leaves us with uncertainty.

The mentioning of 'transformative pedagogy' indicates the importance of transformative ideas of education in critical

- Internal challenges: national education standards and the
rapid growth of Indonesia's productive aged citizens; for citi-
zens with competences and skills for working-economically
dependent
- External challenges: globalization, environmental issues,
advancement of technology and informatics, creative industry
and culture, and international education development (such
as Indonesia's low ranking in TIMSS dan PISA)
1) the changes in learning patterns:
2) Teacher-centered becomes student-centered learning
pattern (teachers, learners, society, and other sources)
3) Isolated teaching/learning becomes networking learning
4) Passive learning becomes active learning (and scientific
approach learning)
5) Individual learning becomes collaborative-based learning
(or team-learning)
6) Single-medium learning becomes multimedia-based
learning
7) Mass-based learning becomes user-based learning (focus-
ing on then uniqueness of the learners)
8) Mono-discipline based learning based becomes multi-
discipline based learning
9) Passive learning becomes critical learning

Figure 8: Rational of the curriculum (source: Permendikbud No.67/2013 and Permendikbud No. 57/2014) 
tradition, mainly the ones with Freirean roots. It might be also meant as the importance of bringing the real world into students' learning-where previously classroom world tended to be separated from the actual world-and at the same time bringing students to the real world in their learning as their development depends significantly on their socio-cultural and temporal contexts as in Vygotskian tradition.

The author argues, it might be as simple as an ordinary statement that teaching and learning should be based on the developmental aspects of the students and as there is what is called theoretical foundation of the curriculum, it becomes the basis for the need of standardization in education.

Fourth, theoretical foundation of the curriculum is in line with the need for systematization, standardization, and managerialism in the first two foundations. Standard-based education and competency-based curriculum are two sub-traditions within systematic and pragmatic tradition according to Null's typology of curriculum making (2011). Here, a curriculum should be containing ideals toward which teaching and learning should be directed. A curriculum is also an institution or an instrument with which the needs of society are served and individual needs and interests are compromised.

Competency-based curriculum making is actually based on competency-based learning where experiential learning is pivotal. Developed in Deweyan pragmatism but with strong neo-behaviorism, competency-based learning necessitates observability and measurability where learning taxonomy with different ability levelling is practically used. Beside the use of Blooms taxonomy (Bloom et al, 1956) and its revisions (such as by Krathwohl, 2002), the curriculum also bases its competence levelling on the structure of the observed learning outcomes (SOLO) as developed by Collis and Biggs (1976) and Gowan and Erikson (1981) (cited in Permendikbud No. 64/2013, Appendix).

Related to human agency, where students should be the agents of their learning, systematic and pragmatic traditions, such as represented by Tyler rationale (1949) is with a tendency to lay emphasis on 
the 'how' aspect (Schubert, 2010) - especially on how a curriculum should be made - while the deeper ontological (what) and axiological (why) aspects tend to be ignored. The needs and interests of the students tend to be just 'consulted' for packaging and a curriculum as a map and a compass or even a source of inspiration for a meaningful journey of life is neglected.

More detailed, first, a standardized curriculum tend to predetermine subject matters with the objectives and materials to be learned by the students. As a critic on Tyler's rational, it is "sharply prescriptive and managerial" (Hlebowitsh, 1995:90). Second, with the predetermined learning objectives, a curriculum is oriented to manipulate the educational environments where students learn in order to control their educational experiences. Third, a standardized curriculum with its technocratic tendency, is not sufficiently dealing with "competing social needs and rival educational philosophies" (Alexander, 2005:348). In this situation, curriculum makers can be easily entrapped thinking that "... learning should be defined primarily in terms of experiences designed to produce predetermined outcomes."

Two other interesting relevant features of Indonesian 2013 curriculum here is what are called as the rational and the characteristics of the curriculum. Again, what we can tell here is that, first, they are presented as in 'slide presentation' instead of in form of a deep and extensive elaboration in a curriculum document. Reading what are in Table 5, for instance, we might quickly react that it is a curriculum with a 'progressive' leap. One may argue that as a policy, such a detail elaboration is unnecessary as the users should explore more by themselves or a thicker curriculum document will restrict the users of the curriculum to further experiment or develop what might be in their minds. Yet, it is clearly a rhetoric. As can be seen in various related policy documents, the tendency to elaborate is densely expressed in terms of procedural and administrative affairs.

Second, the inclusion of concepts such as spirituality, curiosity, creativity, cooperation, intellectuality, psychomotor, society-based school, or society-based learning tend to be merely 


\begin{tabular}{|c|c|}
\hline \multirow{6}{*}{ 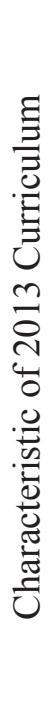 } & $\begin{array}{l}\text { Development of adequate spirituality, curiosity, creativity,- } \\
\text { cooperation, intellectuality, and psychomotor }\end{array}$ \\
\hline & Develop society-based school for society-based learning- \\
\hline & $\begin{array}{l}\text { Provision of sufficient time for the development of attitudes,- } \\
\text { cognition, and skills }\end{array}$ \\
\hline & $\begin{array}{l}\text { Competences (as the standards for teaching-learning activities)- } \\
\text { consist of core class competences and subject-matter compe- } \\
\text { tences }\end{array}$ \\
\hline & $\begin{array}{l}\text { Class core competences become the organizing elements of- } \\
\text { basic competences }\end{array}$ \\
\hline & $\begin{array}{l}\text { Basic competences are developed based on accumulative,- } \\
\text { reinforcing, and enriching between subject-matters and educa- } \\
\text { tion levels-organizationally and horizontaly (Permendikbud } \\
\text { (No.67/2013; Permendikbud NO.57/2014 }\end{array}$ \\
\hline
\end{tabular}

Figure 9: Characteristics of the curriculum (source: Permendikbud No.67/2013 and Permendikbud No. 57/2014)

normative. The author does not find, for example, some real instances of 'negative' facts of human living. The documents tend to be based on the world of education as an ideal world, that students should be conditioned in certain positive environments in order to make them be able to 'curse' and deny the evil world. Therefore, what is dominant then is the tendency of habituation instead of reflection; adaptation instead of adoption; or equilibration instead of resistance and change.

Conversely, in terms of human agency-where the capacities of self-determination, self-expression and self-evaluation are to be constructed-the real world is in need. Capacity for moral judgment is only possible to emerge when there are horizons of significance which are found in the real world and when the students have such an autonomy to decide what to choose and think to make what they do meaningful. Students' capacity to conduct self-evaluation can only be sharpen if they are facing real world problems in order to make them able to construct their strong individual values. So, education with predetermined ideals 
and status quo, if not positioning students as passive recipients of the ideals and the existing institutions, is at least spoiling them in an imaginary ideal world, where they have no existential identities.

In the following discussion, we will see the tendency to obsessively systematize and regulate an official curriculum, as it is found in the policy documents. Interestingly, while policy documents with higher levels should be more general, it is also found that the act on education and government regulations are more detailed to certain extent in managing curricular affairs, in comparison, for instance, with the above curriculum foundation, especially the philosophical ones. This fact then reveals a type of tension if not inconsistency between those regulations.

\section{Regulations on Indonesia's schooling curriculum}

As can be seen in the previous discussion, using Null's typology on curriculum traditions (2011), the policies on curricula in Indonesia can be categorized as situated between systematic and pragmatic. One of the most representative for this argument is how curriculum is defined conceptually and officially as "... a set of plans and regulations about the aims, content and material of lessons and the method employed as the guidelines for the implementation of learning activities to achieve given education objectives" (UU No. 20/2003, Article 1 [19]). In practice, there are two dimensions [or emphasis] of a curriculum. First it is about a plan and administration of what to teach and learn and second it is about the method on how to implement the plan in learning facilitation which also tend to be regulated procedurally and administratively such as in Permendikbud No. 67/2013 and Permendikbud No. 57/2014). It is then unsurprising to read a statement that in the eyes of the educators in Indonesia, a curriculum is "... the written, standardized subject matter guidelines provided by the national central office" (Saud and Johnston, 2006:10).

Curriculum itself is understood in Indonesia as a part of 
what is called as national education standards, "the minimum criteria that a school has to provide in terms of contents, processes, output competences, educational personnel, facilities and equipment, management, budgeting, and educational evaluation". Two standards are most relevant in this discussion, i.e. content and output competences. What is meant as content standards are the "... scope of education materials and levels of competency which are set as the requirements for output competency, competency in learning materials, competency for each subject matter, and syllabus, which requirements must be achieved by learners at given levels and types of education" while output competency $\mathrm{s}$ meant as "the qualification of graduates, which covers attitudes, knowledge and skills" (PP No. 19/2005, Article 35; PP No. 32/2013, Article 77H).

Curriculum development is based on diversification principle, that it should be adjusted according to educational units (such as schools), local resources, and learners' potentials. More detailed, beside it is developed in accordance with national education levelling system, curriculum development is required to take into account any educational efforts to develop religiosity, morality, learners' intelligence and interests, regional and national developmental demands, working-fields, the development of sciences, technologies, and arts, global dynamics, and national unitedness and values (UU No. 2o/2003, Article 36). Moreover, basic curriculum frameworks and the structure of curriculum are determined by national authority in educational affairs. Curricula can be developed by educational units and school committee under the supervision and coordination of local educational authorities (Article 38).

Regarding subject-matters, curriculum for basic and secondary education should cover religious studies, civics, languages (Indonesian, local languages, and foreign languages), mathematics, natural sciences, social sciences, arts and cultures, physical educations and sports, crafts and vocations, and local preferred contents (UU No. 20/2003, Article 37). In practice, at primary levels, subjects are suggested to be taught in thematic- 
integrated method, while at secondary levels they are taught more specifically. In Indonesian 2013 Curriculum, there is also a differentiation between A-grouped subjects-religious studies and moral education, civics, Indonesian, mathematics, natural science, and social sciences, are developed by the central educational authority-and B-grouped subjects-arts and crafts, health, and physical education which are developed by the central educational authority but they can be enriched by the local authority (Curriculum 2013:3).

In order to ascertain learning processes, as the main focus of the standards related to education, schools-or referred as educational units, which can be public (state-owned) or privateare obligated to "... provide educational facilities and equipment required in accordance with pedagogical criteria for learners' de-

\begin{tabular}{|c|c|}
\hline Subjects & Objectives \\
\hline $\begin{array}{l}\text { Religious stud- } \\
\text { ies }\end{array}$ & Religious faithfulness, piousness and morality \\
\hline Civics & Nationalism and motherland-devoting citizen \\
\hline Languages & $\begin{array}{l}\text { Communicativeness in national, local, and foreign } \\
\text { languages }\end{array}$ \\
\hline Mathematics & Basic life skills, logic, and thinking capacity \\
\hline $\begin{array}{l}\text { Natural sci- } \\
\text { ences }\end{array}$ & $\begin{array}{l}\text { Knowledge, understanding, and analytical capacity on } \\
\text { surrounding natural environments }\end{array}$ \\
\hline Social sciences & $\begin{array}{l}\text { Knowledge, understanding, and analytical capacity on } \\
\text { socio-cultural context }\end{array}$ \\
\hline $\begin{array}{l}\text { Arts and cul- } \\
\text { tures }\end{array}$ & $\begin{array}{l}\text { Artistic and cultural senses such as in painting, sing- } \\
\text { ing, and dancing }\end{array}$ \\
\hline $\begin{array}{l}\text { Physical educa- } \\
\text { tion }\end{array}$ & Learners' healthy physicality and mentality \\
\hline Crafts & Practical skills of learners \\
\hline Local contents & $\begin{array}{l}\text { Learners' understanding of their local cultural and } \\
\text { natural potentials }\end{array}$ \\
\hline
\end{tabular}

Figure 9: Subject-matters and objectives (Government Regulation No. 32/2013, supplement of Article 77J) 
velopment and growth for physical, intellectual, social, emotional and spiritual abilities" (UU No. 20/2003, Article 45). Managerially, schools have an autonomy to govern themselves which is called as school-based management system (Article 51).

As to educational evaluation, generally, it is seen as a means to maintain and develop the quality of education, through which the accountability of educational institutions is measured. Evaluation is conducted on students, schools, and educational programs. Regarding evaluation on students' learning achievement, there are two levels of evaluation (UU No. 20/2003, Article 58 [1-2]). First, at school levels, educators conduct regular assessments as a part of learning process, on which continuous development is based. Second, at national levels, there is an evaluation in order to see the achievement of students based on national education standard. So, till today, there is a national examination for students accomplishing basic, lower secondary and upper secondary levels. Admitting it or not, at least, the results of the tests to significant extent influence students' opportunities to be accepted at the next levels of their education.

\section{Children, students, learning and teachers}

Constitutionally, children are basically positioned as having self-determination, that they have the rights "...to live, to grow and to develop, and shall have the right to protection from violence and discrimination" (UUD 1945, Article 28B [2]). In terms of education, parents have the rights to choose the schools for their children and obtain related information on the progress of their education and parents with basic school-aged children (7-15 years) are required to provide them with relevant education (UU No. 20/2003, Article 7 [1-2]).

Defining students or learners generally, as education is not only for children, they are "... the members of any community wishing to develop their potentials through a learning process that is available in a particular stream, level and type of education" (UU No. 20/2003, Article 1 [4]). Accordingly, an education 
should be facilitating the development of the students "... so that they become persons imbued with human values who are faithful and pious to one and only God; who possess morals and noble character; who are healthy, knowledgeable, competent, creative, independent; and as citizens, who are democratic and responsible" (Article 3). As the subjects of learning they should get religious education, an education that is in accordance with their talents, interests, and capacities and that they must be respected in accomplishing their education in accordance with their own learning paces within the reasonable time limitation (Article 12 [1]).

Learning itself is defined as "the process of interaction between learners and educators and learning resources in a particular learning environment" (Article 1 [20]). Correspondingly, on how the quality of education is maintained systematically, evaluation is defined as "a process of controlling, ensuring, and determining educational quality in all components of education in each stream, level, and type of education as a form of responsibility of education provision" (Article 1 [21]). To ensure the quality of the schools as the centers of formal schooling, there is an accreditation scheme, which means "assessment of the feasibility of an education unit and program-based on pre-set criteria" (Article 1 [22]).

As the facilitators in learning, teachers are referred as 'pendidik' (literally means 'educators') who are “... professionals, who have the duty to plan and implement learning processes, to assess education outcomes, to carry out counseling and training, and to conduct research and community service, especially for higher education institution personnel" (UU No. 20/2003, Article 39 [2). Together with supporting educational personnel, there is an emphasis that they must be able to "... create meaningful, joyful, creative, dynamic, and mutually interactive education environment and ... be the role model and uphold the reputation of their institution, profession, and position in accordance with the trust deposited in them" (Article 40). 
Teachers are also said as the agents of teaching with four competences, namely pedagogical, personal, professional (academic), and social competence and that they should have leadership and entrepreneurship in education (PP No 19/2005, Article 28/38). Pedagogical competence is related to the ability to manage teaching and learning, understand learners, conduct relevant assessments, and facilitate learners to actualize their potentials; personal competence is the possession of determined, stable, mature, wise and authoritative personality, a role-model for the students, and noble characters; professional competence is the extensive and deep understanding of the subject[s] taught that enable a teacher facilitate students to accomplish the competence standards required in the national education standards (SNP); and social competence is the ability of educators as members of a learning society to effectively communicate and socialize, not only with their students, teaching colleagues, school staffs, parents, but also with society as a whole (PP No. 19/2005, Supplement). More practically, teachers should create meaningful, enjoyable, creative, dynamic and dialogical educational atmosphere (UU No.20/2003, Article 40 [2]).

To sum up, how a curriculum is defined and regulated as well as what learners and teachers are in the policy documents again represents a tension between the tendency to regulate and entrust. Students and teachers can be seen clearly seen as human beings who are to be entrusted as the agents of their life, teaching, or learning. Yet, the tendency to regulate, systematize, control, or centralize educational practices, mainly administratively, risks the autonomy of schools, teachers, and students. The tension shows the ambiguity in the documents if not ambivalences.

\section{Conclusion: towards a human agency-based curriculum}

The article starts with a general phenomenon that a curriculum is mostly understood as a plan for teaching and learning with dominant influences of 'the national central office'. The elaboration of the relevant state policy documents tend to confirm 
such understanding, where there is a resilient predisposition on what an official curriculum should be. Theoretically, such predisposition is rooted in the systematic and pragmatic traditions in curriculum making, where the ideals of what worth learning are decided based on what works in the adult's world. Students, as the subjects of learning-with their needs, interests, and primarily their unique existences-thus are jeopardized. If they are positioned as a commonplace, as in Schwab's theorization, it is more as what Alexander argued as “... for the purpose of packaging predetermined social objectives to make them appealing to students, rather than to actively engage their genuine aspirations and concerns" (Alexander, 2005

Secondly, there is a tension in the series of policy on curriculum, between the tendency to strictly regulate what worth learning for students and the notions-mostly in form of philosophical or ideal statements-to confidently entrust teachers and students as human beings through recognizing their needs, interests, potentials, and identities. There is also a problem with the contents of the regulations in terms of their functions as general guidelines in education. For instance, when the Act on national education system mandates 'competency-based curriculum' as the official type, any other alternatives will be sidelined and there will be inevitable pragmatic 'forging' in order to adjust the derivative policies.

Based on the theoretical framework, the tendency to sternly systematize, regulate, and control education and curriculum making represents receptive-reproductive propensity. Here, students are positioned more as passive recipients of predetermined worthwhileness instead of the agents of their learning. There is then insufficient room for the conditions and construction of students' capacity for self-determination, self-expression, and self-evaluation.

However, there are concepts, statements, and claims-more as jargons-in the documents, for sure, that signify the possibilities for reflective-transformative curriculum where students are 
positioned as the agents of learning. In order to provide the space for a human agency-based curriculum, there are at least three things should be ascertained. First, there should be deeper and clear elaborations of those concept, especially of how they are conversed as there are seemingly contradicting ideas such as in the philosophical, sociological, psycho-pedagogical, and theoretical foundations and how they are connected to the real world of life and learning which are not always as ideal as in the world of ideas. A more compact, representative but succinct curriculum document is needed. Yet, there is no need to make it as teaching and learning manual, but more as a reference. Second, there must be a stronger consciousness that systematic-technocratic tradition in curriculum making jeopardizes the existential potentials of the students. The quest for observability and observability on one side secures policy-makers or job markets such as stated in the rational of the curriculum, but it contradicts humanistic elements of education itself. Third, as there has been a mandate on a school-based curriculum, what is needed, the author argues, is more 'trust' on the schools and teachers. There might be unintended problems with more decentralization. Yet, education is about building trust, and if observability and measurability are still seen as non-negotiable, any new instruments should be concise and applicable which are enacted after reliable experimentations and researches.

Academically, there should be further research on the document of the curriculum, especially on how the core and basic competences actually are, whether they are supportive for human agency based learning or otherwise. This article itself cannot be claimed as having based on an exhaustive research. There should be further researches, especially on how an official curriculum in Indonesia is substantially produced, reproduced, or changed. 


\section{BIBLIOGRAFI}

Alexander, H.A. (2005). Human Agency and the Curriculum. Theory and Research in Education, 3(3), 343-369.

Bloom,B. S., Engelhart,M. D., Furst,E. J., Hill,W. H.,\& Krathwohl, D. R. (Eds.). (1956). Taxonomy of educational objectivities: The classification of educational goals. Handbook I: Cognitive domain. New York: David McKay.

Bruner, J. (1977). The Process of Education. Harvard: Harvard University Press.

Hlebowitsh, PS. (1995) Interpretations of the Tyler Rationale: A Reply to Kliebard, Journal of Curriculum Studies, 27:1, 89-94.

Jordan, A., Orison, C., \& Stack, A. (2008). Approaches to learning: a guide for teachers. Berkshire: McGraw-Hill Open University Press.

Kamus Bahasa Indonesia. (2008). Jakarta: Pusat Bahasa, 2008

Kemendikbud. (2012). Dokumen Kurikulum 2013. Jakarta: Kemendikbud

Krathwohl, D.R., Bloom, B.S, and Masia, B.B. (1980). Taxonomy of Educational Objectives: Book 2 Affective Domain. New York: Longman.

Marzano, Robert J., Kendall, JS. (2007). The New Taxonomy of Educational Objectives. California: Corwin Press.

Null, W. (2011). Curriculum: from theory to practice. Maryland: Rowman \& Littlefield Publishers, Inc.

Permendikbud No. 54/2013 tentang Standar Kompetensi Lulusan Pendidikan Dasar dan Menengah

Permendikbud No. 57/2014 tentang Kurikulum 2013 Sekolah Dasar/ Madrasah Ibtidaiyah

Permendikbud No. 64/2013 tentang Standar Isi Pendidikan Dasar dan Menengah

Posner, G.J. (2004). Analyzing the Curriculum. New York: McGrawHill, Inc.

PP No. 10/2005 tentang Standar Nasional Pendidikan 
Toward A Human Agency-Based Curriculum

PP No. 32/2013 tentang Perubahan Atas Peraturan Pemerintah No. 19/2005 tentang Standar Nasional Pendidikan

Rousseau, JJ. (1979). Emile or on Education. USA: Basic Books.

Saud, U. \& Johnston, M. (2006). Cross-cultural influences on teacher education reform: reflections on implementing the integrated curriculum in Indonesia. Journal of Education for Teaching: International research and pedagogy, 32 (1), 3-20.

Schubert, W.H. (2010). Journeys of Expansion and Synopsis: Tensions in Books that Shaped Curriculum Inquiry, 1968-Present. Curriculum Inquiry, 40 (1).

Schwab, JJ. (1971). The Practical: Arts of Eclectic. The School Review, 79 (4), 493-542.

Stevens, AM. \& Schmidgall-Tellings, AE. (2010). A comprehensive Indonesian-English Dictionary. Ohio: Ohio University Press.

Taylor, C. (1985a). Human agency and language: Philosophical Papers. Cambridge: Cambridge University Press.

Taylor, C. (1985b). Philosophy and the Human Sciences: Philosophical Papers. Cambridge: Cambridge University Press.

Tyler, R. (1949). Basic Principles of Curriculum and Instruction. Chicago: University of Chicago Press.

UU No. 20/2003 tentang Sistem Pendidikan Nasional UU No.20/2003 tentang Sistem Pendidikan Nasional.

UUD 1945 (Indonesia's Constitution)

Vasquez-Levy, D. (2002). Bildung-centred Didaktik: a framework for examining the educational potential of subject matter. Journal of Curriculum Studies, 34 (1), 117-128. 